\title{
MATHEMATICAL KNOWLEDGE IN ELEMENTARY SCHOOL AND FOR FUTURE ENGINEERS
}

\author{
Natalija Sergejeva $^{1}$, Aivars Aboltins ${ }^{1}$, Liene Strupule ${ }^{1}$, Baiba Aboltina ${ }^{2}$ \\ ${ }^{1}$ Latvia University of Life Sciences and Technologies, Latvia; ${ }^{2}$ University of Latvia, Latvia \\ natalija.sergejeva@1lu.lv, aivars.aboltins@inbox.lv
}

\begin{abstract}
The basic mathematical skills are acquired in elementary school. This research compares basic mathematical knowledge of three groups - elementary school graduates, students from four different specialties (future engineers) with varied levels of higher mathematics and future teachers of mathematics. The study concludes that students from elementary school have better knowledge in comparison with students from university. The possible reason for that is resent acquirement of the study material and examination at finishing elementary school. It is also observed that several students had taken gap years between school and university, but the current educational system in Latvia does not require entrance examinations. Modern engineering education is founded on good basics of mathematics that are acquired in elementary school. The experience shows that acquisition of the course of mathematics at elementary school is the determinant factor for further successful acquisition of the course of higher mathematics.
\end{abstract}

Keywords: mathematics, basic education, engineering students, future education.

\section{Introduction}

Mathematics is foundational in many ways that influences our decisions in areas of our lives. Teaching and learning mathematics is at the heart of education. Learning mathematics aims to link school to everyday life, provide skill acquisition, prepare students for the workforce, and foster mathematical thinking [1]. Mathematics involves learning to problem- solve, investigate, represent, and communicate mathematical concepts and ideas, and making connections to everyday life [1].

Mathematical competence is acknowledged in the European Union as being one of the most important competences that is necessary for getting personal satisfaction by active participation in civil and social life, and making professional career in the knowledge society of the $21^{\text {st }}$ century. All adults need appropriate knowledge of mathematics for their professional development, work and valuable involvement in the society.

Today in Latvia, in accordance with the data of the Ministry of Education and Science, increasingly less numbers of students at schools take centralised examinations in exact sciences. Also in the higher educational establishments the percentage of graduates in the spheres of mathematics, science and technologies is one of the lowest in Europe. Let us say that one of the compulsory examinations in Latvia is in mathematics. Considering the above mentioned and taking into account the disproportion threats of the labour market in future, it is necessary to increase the proportion of students in natural and engineering sciences. The number of students having low results in mathematics in 2020 should reduce from $20 \%$ in 2012 to $15 \%$, as well as the proportion of graduates from higher educational establishments (ISCED 5. and 6.) in the spheres of STEM should increase from $19 \%$ of the total number of graduates in 2012 to $27 \%$ in 2020 [2].

The system of education in Latvia, including education in mathematics, at present is on a way to changes. In the nearest future years it is planned to transfer to the new system based on competences. There have been reforms in mathematical education recently in many European countries, the reason for it being application of the approach based on the learning results that is necessary to train young people better for personal wellbeing as well as for social and working life [3].

Nowadays, young people often think that it is not so important to know how to perform mathematical calculations on paper, as there are many technologies developed, by help of which it is possible to do many things. They consider that computers will do everything instead of people and that it is not necessary to think about it. Such opinion has been experienced in the systems of education in many countries, for instance, the USA.

A concept paper published by the American Mathematical Society has been influential in identifying some common areas of agreement about mathematics education [4]. The identified areas of the agreement are based on three fundamental premises: 
1. Basic skills with numbers continue to be important and students need proficiency with computational procedures.

2. Mathematics requires careful reasoning about precisely defined objects and concepts, mathematics is communicated by means of a powerful language, which vocabulary must be learned, because the ability to justify mathematical statements is fundamental.

3. Students must be able to formulate and solve problems; it means to translate the problem from everyday language into a precise mathematical language and so on.

The areas of agreement emerging from these premises include:

1. Mathematical fluency requires automatic recall of certain procedures and algorithms.

2. Use of calculators in instruction can be useful, but must not impede the development of fluency with computational procedures and basic facts.

3. Using and understanding the basic algorithms of whole number arithmetic is essential.

The authors of the article have large experience at work with students of the secondary school level as well as at teaching courses of different depth and level at higher educational establishments. Recently, a trend has often been observed that many first year students discontinue their studies at higher educational establishments, mentioning inability to acquire the course of mathematics as the reason for it. The authors are sure that the problem is not in the acquisition of higher mathematics as such, but in the fact that young people do not have the elementary basic knowledge in mathematics that could be learned already at elementary school.

The authors are certain that at elementary school the basic things are to be taught, which should be learned by all students. It is better to have a less number of the topics for learning, but to have higher quality of the learned material. After finishing elementary school, students need to have skills to apply the basic knowledge and understand the obtained result. The above mentioned is in compliance with the conception of the new educational system based on competences, in accordance to which elementary school education is the core of all education. Finishing elementary school students should know how in multiform life situations, carefully applying mathematical instruments, to do calculations, process data, apply characteristics of shapes, to make general judgements and perform mathematical modelling, to choose the right approach/strategy in problem situations, understand the necessity for demonstrations and make sound judgements [5].

The aim of the present research is to determine and compare the knowledge and basic skills, related to the basic course of mathematics at elementary school, of students of different groups. The practical experience of the authors shows that acquisition of the course of mathematics at elementary school is the determinant factor for further successful acquisition of the course of higher mathematics.

As the authors are working at higher educational establishments and at the same time also at secondary schools, it was possible to ask the students of year 10 to do an analogous task and to compare the results. The choice of the target audience for the investigation can be substantiated also by the fact that the world wide known investigation PISA is performed including students from schools with the age during testing from 15 years and 3 full months to 16 years and 2 full months (most part of students finishing elementary school are exactly of this age) [6]. Besides, also due to the fact that according to the Russian scientist Krutecky, the mathematical skills of young people should be studied, when they start acquiring algebra and geometry, as before that it is possible to discuss the mathematical skills only conditionally, but later on they have already developed to some extent [7].

\section{Materials and methods}

In total, 271 young people participated in the research: 13 first year students of the University of Latvia (future teachers of mathematics), 45 first year engineering specialty students of the Latvia University of Life Sciences and Technologies (LLU), the total number of the credit points (KP) for whom in mathematics is $11 \mathrm{KP}, 89$ first year students of the LLU, the total number of the credit points for whom in mathematics is 5, and 124 elementary school leavers (from year 10 of two different schools). The research was performed in September, 2017.

All participants were offered the same task, which includes the basic elements of elementary mathematics that are necessary for acquisition of mathematics at high school as well as the course of higher mathematics. In total, 18 tasks were offered to be solved within one learning session (40 
minutes): the first seven were assessed with one point for every solved task, for the next four it was possible to get up to two points for every task and the last seven offered a possibility to get 3 points for every completely solved task. It was possible to get maximum 36 points for the tasks. Examples of the offered tasks are shown in Table 1.

The following topics were included in the test: Fractions and percentages of quantities (4 points), Solving of different types of quadratic equations (4 points), Operations on fractions and decimals (8 points), Operations on algebraic fractions (7 points), Systems of linear equations in two variables (2 points), Solving literal equations (2 points), Graph of linear function (3 points), Solving inequalities (3 points), Ordering of numbers ( 2 points), Pythagorean theorem (1 point).

Table 1

Some examples of test tasks

\begin{tabular}{|c|c|c|}
\hline $\begin{array}{c}\text { Task } \\
\text { number }\end{array}$ & $\begin{array}{l}\text { Number } \\
\text { of points }\end{array}$ & The task text \\
\hline 1 & 1 & What is $15 \%$ of $420 ?$ \\
\hline 3 & 1 & Calculate $\frac{6}{25}: 3 \frac{3}{5}$ \\
\hline 4 & 1 & Calculate $\left(\frac{1}{2}\right)^{-3}$ \\
\hline 5 & 1 & $\begin{array}{l}\text { One of the legs in right - angle triangle is } 8 \mathrm{~cm} \text {, the hypotenuse is } \\
10 \mathrm{~cm} \text {. Calculate the other leg of triangle. }\end{array}$ \\
\hline 6 & 1 & Simplify the fraction $\frac{a b-b^{2}}{b^{2}}$ \\
\hline 8 & 2 & $\begin{array}{l}\text { Arrange and write the numbers in decreasing order } \\
\begin{array}{lllllll}-1.7 & 0 & 2.4 & -\frac{3}{5} & 2 \frac{2}{9} & -0.5 & -1 \frac{1}{3}\end{array}\end{array}$ \\
\hline 11 & 2 & Express $b$ from the expression $\frac{4 a T}{3 c+b}=7$. \\
\hline 15 & 3 & $\begin{array}{l}\text { Graph of the function } y=k x+2 \text { passes through the point }(3 ;-1) \text {. } \\
\text { Calculate } k \text { and construct the graph of the given function. }\end{array}$ \\
\hline 17 & 3 & $\begin{array}{l}546 \text { students study at the school. How many girls are studying at this } \\
\text { school, if the number of boys is } \frac{6}{7} \text { from the number of girls? }\end{array}$ \\
\hline
\end{tabular}

\section{Results and discussion}

Summarizing the results it can be seen that the students from year 10 have better knowledge in the basics of mathematics than the first year students of the engineering specialties. So, at school A the average result was $58 \%$ of the possible maximal number of points. At school B it was $48 \%$. The average result of the first year students of the LLU was from $33 \%$ to $41 \%$ of the possible maximal number of points (See Fig. 1). It could be explained by the fact that students at school revised the elementary school material in mathematics before the test. 


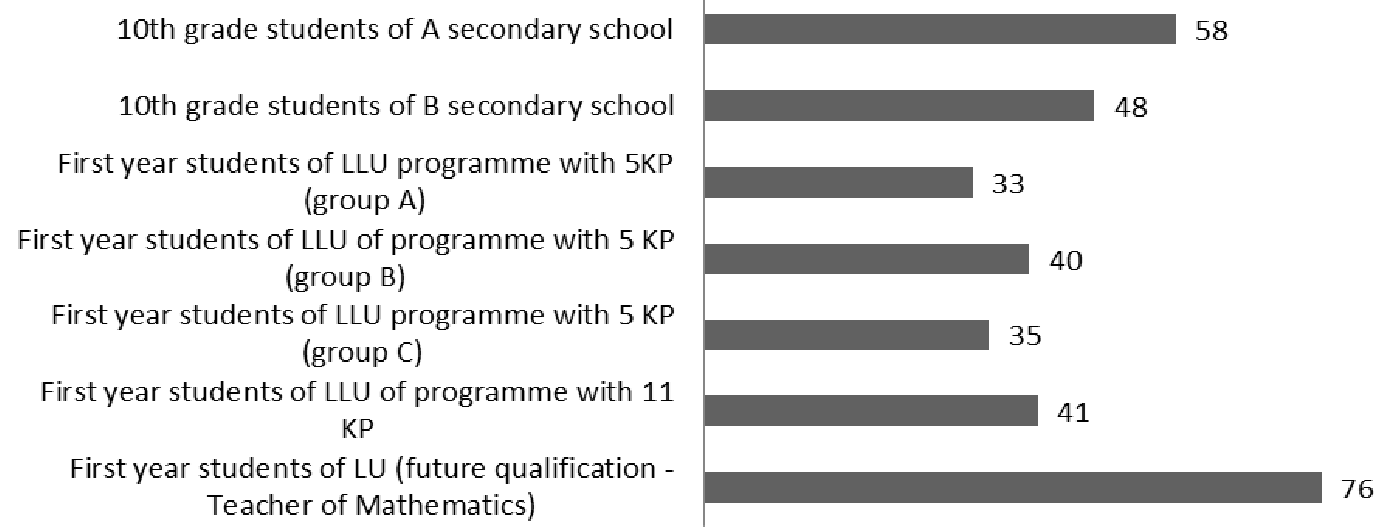

Fig. 1. Average results of max test points (\%) for different student groups

The combined results of the year 10 students of both secondary schools can be seen in Fig. 2.

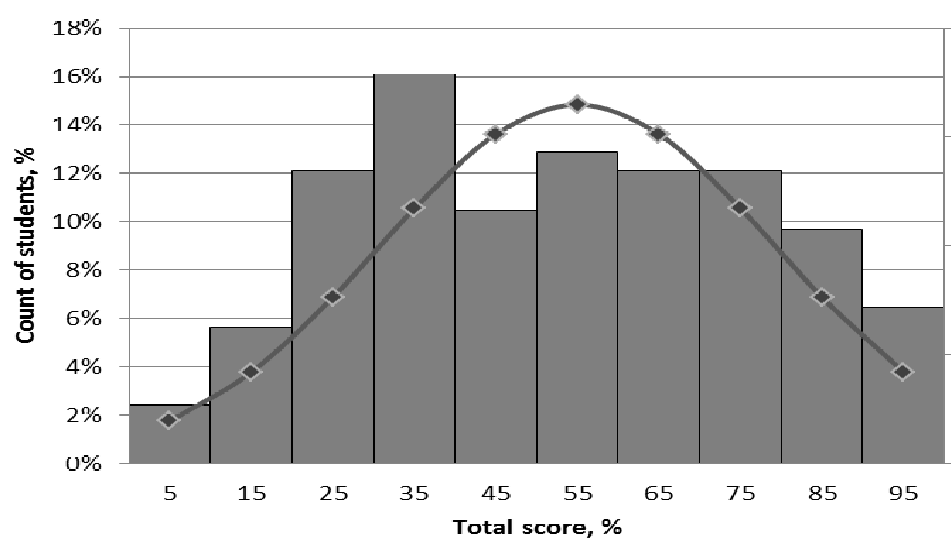

Fig. 2. Test results of $10^{\text {th }}$ grade students from two different secondary schools

In Fig. 3 and Fig. 4 one can see the distribution of the results of the Latvia University of Life Sciences and Technologies 1st year student groups and the corresponding normal distribution curve (or Gaussian curve).

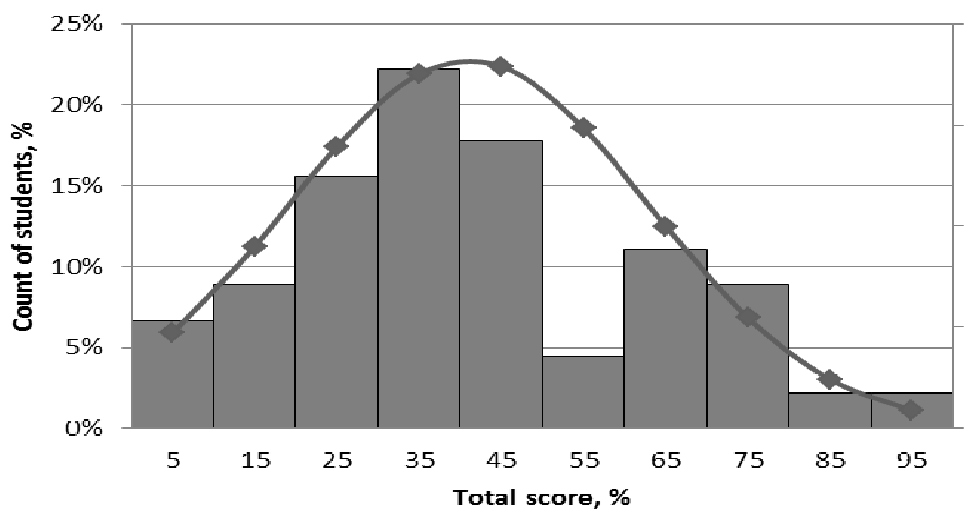

Fig. 3. Test results of first year students for LLU of programme with $11 \mathrm{KP}$

According to these results it can be quite surely prognosticated that about $30 \%$ of the new students will discontinue their studies in the first year, mentioning mathematics as a reason for it. It must be stressed here that the main cause for it is the lack of basic knowledge in mathematics. 
The amount of basic knowledge in mathematics of the students represented in Fig. 4 is even worse. It can be seen that for more than $45 \%$ of the new students the acquired basic knowledge in mathematics adds up to about $30 \%$, but for more than $16 \%$ - less than $10 \%$.

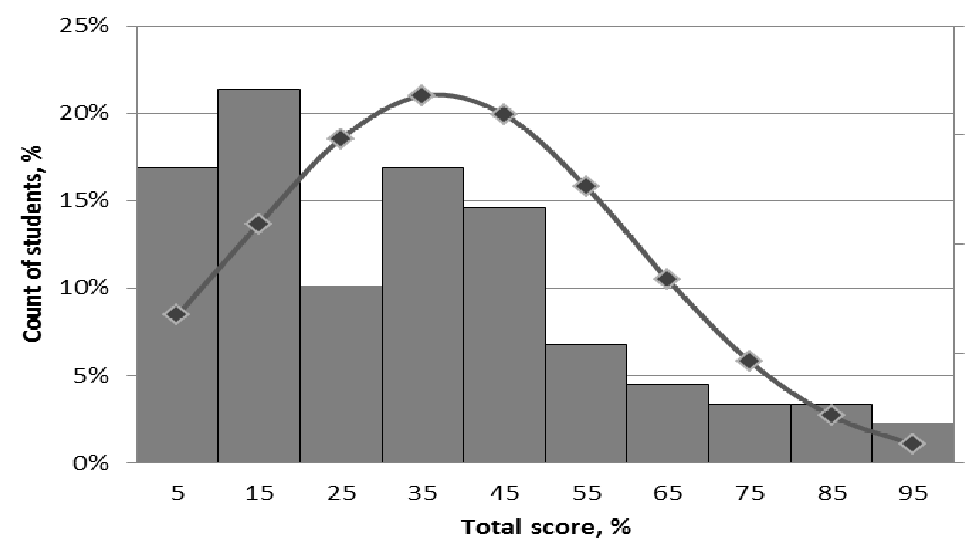

Fig. 4. Test results of first year students for $L L U$ of three different programmes with 5 KP

All these given data were compared to the level of knowledge in elementary mathematics of the students (future teachers of mathematics), who have entered the LU, Fig. 5. It should be noted that in this case the students at school have chosen mathematics as the aim for their future. Usually the students, who are motivated to learn and understand mathematics in a more complicated way, choose this specialty.

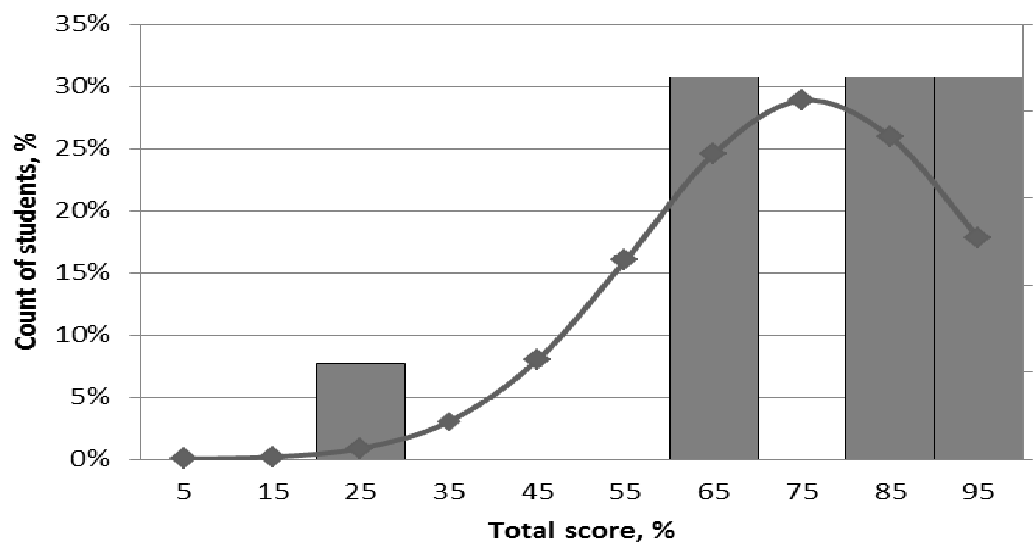

\section{Fig. 5. Test results of first year students of LU (future qualification - Teacher of Mathematics)}

Analysing the test results, it can be concluded that students desperately lack elementary school knowledge and skills in mathematics and arithmetic. In the corrected students' papers there are very many mistakes exactly in elementary mathematics. The students make mistakes operating with numbers, they cannot reduce the algebraic fractions correctly (do not consider that only the factors can be reduced), do not know the basic formulas of algebra and do not use them correctly, for instance, in exponentiation. Examples of some of the typical mistakes can be seen in Fig. 6.

The diagrams in Fig. 2-4 show that the assessment proportion is not uniform; two big maximums can be observed analysing the school students' results as well as the university students' results. It is, according to the opinion of the authors, natural. Many youngsters, who should possibly acquire some craft, enter general education schools and after finishing decide to study at higher schools, although they lack in the basic knowledge. The authors are of the opinion that secondary schools are not interested in steering the students to professional technical schools as "money follows the student". The result of this can be seen in the diagrams of the student assessment, where also two maximums can be seen. 


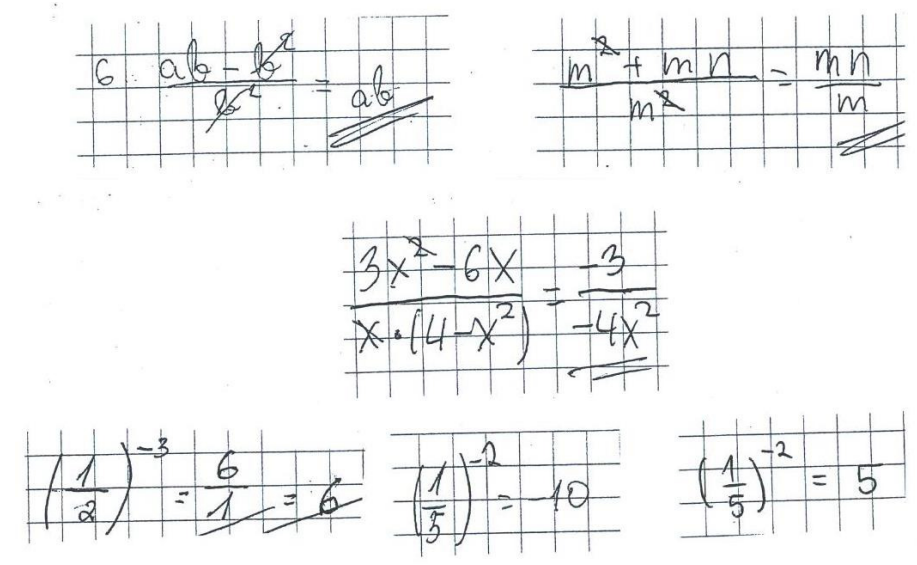

Fig. 6. Examples of some of most typical student mistakes

According to the opinion of the authors, the problem is in today's system of education. There are too many higher educational establishments in Latvia that try to keep students by all means. In accordance with the data of the Central Statistical Bureau for the beginning of 2017 in Latvia, there are 1.95 million inhabitants and 58 higher schools and colleges, consequently about 29.7 higher schools per one million inhabitants [8].

In many higher schools the first year students are offered additional sessions to revise the course taught at school. Also the authors of the present article have experience in conducting such courses. Still, the authors think that such additional sessions could help those students, who got the assessment above $40 \%$ in such type of work. Recently it can be observed that students enter higher schools after some break, when they have worked for a few years before that. For such students it would be preferable to have additional sessions at the beginning of the year. It would brush up the knowledge acquired before with no need to learn everything from the beginning.

\section{Conclusions}

1. Students desperately lack elementary school knowledge in mathematics.

2. Analysing the students' papers, it can be concluded that up to $30 \%$ of the students will have problems with acquisition of the course in mathematics and, as a result, also with acquisition of other study courses.

3. $20-30 \%$ of the students, as the analysis of the test results shows, will possibly discontinue their studies already being in the first year of studies.

4. Additional sessions that in several higher schools are organised at the beginning of the year with the aim to revise the course of mathematics acquired at school, could help those students, who have got the assessment $30-50 \%$ in the described tests.

\section{References}

[1] Ontario Ministry of Education. The Ontario Curriculum Grades 1-8: Mathematics. Toronto: Queen's Printer for Ontario. 2005, [online] [05.04.2018]. Available at: http://www.edu.gov.on.ca/eng/curriculum/elementary/math18curr.pdf

[2] Izglîtīibas attīstības pamatnostādnes 2014.-2020. gadam (Education development Guidelines 20142020. year), 2014. [online] [05.04.2018]. Available at: https://likumi.lv/doc.php?id $=266406$ (In Latvian)

[3] Matemātikas izglītība Eiropā: kop̄̄gie izaicinājumi un valstu rīcībpolitika. (Mathematical Education in Europe: Common Challenges and National Policies) [online] [05.04.2018]. Available at: http://viaa.gov.lv/files/news/8066/matematika_viaa_2012_28.08..pdf (In Latvian)

[4] Ball D., Ferrini-Mundy J., Kilpatrick J., Milgram J., Schmid W., Schaar R. Reaching for common ground in K-12 mathematics education. Notices of the American Mathematical Society, 52 (9), 2005, pp.1055-1058.

[5] Izglîtīiba mūsdienīgai lietpratībai mācību satura un pieejas apraksts. (Education for advanced skills, description of study content and approach) [online] [05.04.2018.] Available at: https://domaundari.lv/cepure/Macibu \%20satura \%20un \%20pieejas \%20apraksts.pdf (In Latvian) 
[6] Programme for International Students Assessment. [online] [05.04.2018.] Available at: http://www.oecd.org/pisa/

[7] Крутецкий В. А. Психология математических способностей школьников.(Psychology of mathematical abilities of schoolchildren)- М.: Издательство "Институт практической психологии", 1998, 416 p. (In Russian)

[8] Centrālā statistikas pārvalde. (Central Statistical Bureau) [online] [05.04.2018.] Available at: http://www.csb.gov.lv/ 